\title{
Does economics have an effect? towards an economics of economics
}

\section{Working Paper}

\section{Author(s):}

Frey, Bruno S.

Publication date:

2000

Permanent link:

https://doi.org/10.3929/ethz-a-004373389

\section{Rights / license:}

In Copyright - Non-Commercial Use Permitted

\section{Originally published in:}

Working paper / Institute for Empirical Research in Economics 36 


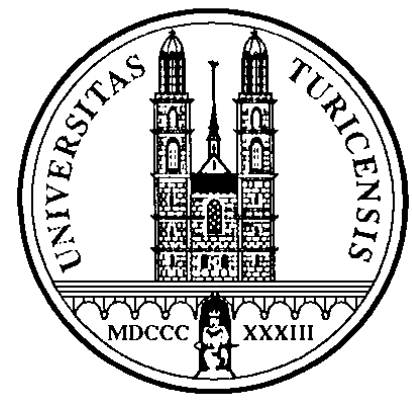

Institute for Empirical Research in Economics

University of Zurich

Working Paper Series

ISSN 1424-0459

Working Paper No. 36

Does Economics have an Effect?

Towards an Economics of Economics

Bruno S. Frey

February 2000 


\title{
DOES ECONOMICS HAVE AN EFFECT?
}

\section{Towards an Economics of Economics}

\author{
Bruno S. Frey* \\ University of Zurich
}

\begin{abstract}
Due to its formality and highly analytic thinking, economics is often attributed a leading role among the social sciences and a prominent position as contributor to economic or social issues in the real world. Fact is, however, that the empirical proof for such a claim is either missing or anecdotal.

This paper aims to outline the "economics of economics". It surveys and compares approaches of impact measurement such as a production function of economics or the demand and supply of trained economists and discusses the determinants of the strength of the influence of economics. It furthermore discriminates between the impact of economic ideas versus that of economists as scientists or politicians.
\end{abstract}

JEL classification: A11; A12; A14

Keywords: Economics of Economics, Role of Economics, Role of Economists

Economists tend to display a remarkable degree of self-confidence. They do so when they claim that their analytical approach - often relying on a formal language - makes economics the "Queen of the Social Sciences". Unsurprisingly, they also take it for granted that economics contributes to the solution of social problems. And yet, it is this point where they are misled. While in other areas of economics they would not easily accept that looking at the input side allows the effect on output to be assessed, they do so when it comes to evaluating the effects of economic theory on economic or political development. It is striking that a systematic analysis of the impact of economic ideas is lacking. Instead, economists refer to their participation in advisory boards, i.e. the input side of the political

\footnotetext{
${ }^{*}$ Bruno S. Frey is professor of economics at the University of Zurich, Institute of Empirical Economic Research, Blümlisalpstr. 10, 8006 Zürich, Switzerland, Tel. 01/ 634'37'31, Fax. 01/ 634'49'07, e-mail bsfrey@iew.unizh.ch.
} 
process. Their participation might or might not have an effect; the effect might lead to an improvement or work to the detriment of social welfare. In any case, a systematic discussion is needed.

In what follows, such an analysis is attempted. Section I deals with the widely different views of the influence of economics on society. Section II distinguishes and discusses three avenues to the study of the topic: (A) The use of a production function between economics as an input and social outcomes as outputs; (B) The influence of ideas; and (C) the influence of economists as persons. Section III discusses the determinants of the strength of the influence of economics. Finally, section IV provides a personal evaluation of the impact of economics and economists on economic policy and society more generally.

\section{Different Views}

One of the best-known statements about the role of economists is by Keynes (1936: 383-4) "(T)he ideas of economists and political philosophers ... are more powerful than is commonly understood. Indeed the world is ruled by little else". But it should be noted that economists have to share this position with political philosophers, who are rarely assumed to have much influence on the world. Hayek (1991: 37) agrees with Keynes but adds: " ... economists have this great influence only in the long run and indirectly". Fifty years after Keynes, Hahn (1985) felt it necessary to write a whole essay "In Praise of Economics". Yet other economists such as Krugman (1996) or Schultze (1996: 31), though not denying the effect economic ideas may have, cautiously argue that the main contribution of economics is that it helps to prevent "major blunders".

But there are also contrasting views. The Economist (1997: 13) writes about the "Puzzling Failure of Economics", and the New Yorker (Cassidy 1996: 50-1) comments: " ... a good deal of modern economic theory, even the kind that wins Nobel Prizes, simply does not matter much". Leading economists are often unknown beyond their narrowly defined field, while at the same time only few economic books catch the attention of the general public. Politicians show less and less interest in the economic literature, but turn to academics with a higher profile from other fields. While it could be argued that the two statements above 
are responses typical of the media, this cannot be said of the following remarks. According to Galbraith (1975), "the economic profession - I choose the words with care - is intellectually bankrupt. It might as well not exist". Similar statements can be heard from the ideologically opposite side. "We economists in recent years have done vast harm - to society at large and to our profession in particular by claiming more than we can deliver" (Friedman 1972: 12). Clower (1989: 23), a former editor of the American Economic Review, goes even further: "Much of economics is so far removed from anything that remotely resembles the real world that it is often difficult for economists to take their subject seriously". And Stiglitz (1998: 5), a former chairman of the U.S. Council of Economic Advisors, is seemingly surprised to find that the environment of the White House is dominated by a completely different economic logic. He asks in an almost desperate manner: "Why is it so difficult to implement even Pareto improvements?" With respect to economists' contribution to economic development, Reder (1999: 286) concludes that their "effect has not been a major one". Even Nobel Prize recipients, such as e.g. Leontief (1971) or Vickrey, attack their own field (see Cassidy 1996: 50). The most devastating judgement is however by Blaug (1997: 2) "modern economics is sick; economics has increasingly become an intellectual game played for its own sake and not for its practical consequences".

Different as the aforementioned statements sound, they all assume that economics has an impact. In contrast to this, economic theory à la Chicago claims that the economy is in an efficient equilibrium position. Consequently, economics cannot contribute anything beyond what is part of this equilibrium. If economists nevertheless believe that they can have an effect on the economy, they are mistaken (Stigler 1982, Becker 1985, Wittman 1989).

These and other claims of the existing or missing effect of economics on society (see also Reder 1999) are good to read and may reveal important aspects. However, they express more or less informed sentiments and personal opinions, if not frustration. Self-interest may also play a role when the authors attack or defend economics. In order to clarify the effect of economics on the economy and society, a more analytical approach is needed. 


\section{Three Approaches}

The influence of economics on the economy and society may be analyzed by focusing on three aspects:

A. An aggregate production function systematically linking the input provided by economics to the output in the form of the state of the economy and society (section A).

B. The influence via economic ideas (section B). What are "economic" ideas, i.e. is there a consensus of what economists can contribute at all, and how does the transfer process of these ideas into reality take place? One may distinguish several routes:

(a) The internal academic process revealed by scientific publications;

(b) The impact of economics on other sciences;

(c) The influence via the media;

(d) The application of specific economic proposals in economic and social policy; and

(e) The analysis of particular policy episodes and policy areas.

C. The influence as persons (section C).

The following aspects can be considered:

(a) The education of economists;

(b) The number and compensation of economists;

(c) The market demand for economists outside academia;

(d) Advisory institutions, besides the university scientific networks, think tanks, and private firms, etc; and

(e) Economists as politicians.

Only some of these aspects can be discussed in the framework of this article, and this at no great depth. The purpose of the paper is different, namely to give the reader an impression of the width of possible ways to capture the claims of the impact of economics on society. 


\section{A. Production Function}

The state of an economy and society $\mathrm{S}$ can be assumed to depend on three input factors: Economic theory E, other Social sciences O, and additional factors F.

$$
\mathrm{S}=\mathrm{f}(\mathrm{E}, \mathrm{F}, \mathrm{O})
$$

The state of the economy S can be captured by (various) aspects, such as the level or the rate of growth of per capita income, the rate of unemployment, the rate of inflation, the value of the stock of firms traded at the stock exchange, the subjective evaluation of wellbeing or of happiness (see e.g. Oswald 1997, Frey and Stutzer 2000), the intensity of inventive activity etc. The input of economics can be measured by the number, share or growth rate of economists employed, or by the number and quality of research published and quoted (see sections 2 and 3). The input by other sciences (variable $\mathrm{O}$ ) can be captured by the corresponding figures for political science, policy science, sociology or law.

There are many different views of what the functional relationship looks like. According to Allen (1979: 18-19): " ... a country's economic progress is in inverse proportion to the distinction of its economists". Wyplosz (1999: 60) observes: "The economic successes of France and Japan seem to indicate that economic policy can be carried out perfectly well without economics". Stigler (1982: 63) believes that "(e)conomists exert a minor and scarcely detectable influence on the societies in which they live" and, with respect to publications, Tullock (1984: 229) finds: " ... the average article in economic journals has very little prospect of contributing to the well-being of the world".

To my knowledge, the production function for economics has not been estimated, with the exception of Barro (1993), who ironically described the relationship between the economists in the U.S. Council of Economic Advisors and the state of the economy in the following way:

" ... economic outcomes (measured by the contribution to the misery index) and the credentials of the chairman of the council (measured by citation counts) are essentially uncorrelated. Although some who are highly ranked on citations ... do well on performance, the highly ranked Mr. Schultze ends 
up with the worst economic outcomes. Moreover, some of the chairmen who ranked low on citations ... emerge with good economic performance ${ }^{\prime \prime}$.

Estimates of "spillovers" on commercial innovations of academic research, as undertaken e.g. by Jaffe (1989) or Acs, Audretsch and Feldman (1991), may be interpreted as a special variant of scientific production functions. These studies, based on experiments, address the question to which extent an economic background reduces co-operative behavior necessary to mitigate an adequate supply of public goods. Frank, Gilovich and Regan (1993) conclude that students of economics reveal more egoistic and cynical behavior than students of other subjects, and that this tendency increases with the length of study. Other studies claim that the differences found are the result of self-selection rather than "proving" the impact of education (see Carter and Irons 1991, and Frey, Pommerehne and Gygi 1993, and Laband and Beil 1999).

One reason why we find only scattered attempts to capture the influence of economics (or other sciences) on the economy and society, is that to construct a production function poses a formidable task. Nevertheless, such an attempt offers three advantages: (1) Attention is focussed on the distinction between input and output of economics, a distinction often overlooked when discussing the issue; (2) The researcher is forced to systematically analyze the relationships involved, and to measure the identified factors. (3) Both microand macro-economic determinants can be included.

Yet such a proceeding faces serious problems. Most likely, the prerequisites for estimating a production function are not fulfilled: " ... the market [for economics] at the production possibility frontier is inefficient in the sense that, given the output of pure theory, we could achieve a better output of applied work. We are not at the production possibility frontier" (Mayer 1993: 10). Following Reder (1999), this gap can be explained by the disregard for empirical research. Moreover, the specification of the production function is far from clear. Thus, for example, the time lag between new economic ideas and the effect on the economy and society is uncertain ${ }^{2}$. Causality is also an open question. It may well be that it

\footnotetext{
${ }^{1}$ Magee (1992) estimated a production function for lawyers using a cross-section analysis for 54 countries. Taking into account various other factors $(\mathrm{F})$, it turns out that lawyers have an inverted U-shaped influence on economic growth, i.e. there is an optimal number of lawyers. Having too many lawyers produces major negative external effects.

${ }^{2}$ For example, Schelling (1997: 146) states that it took twenty years until economic proposals entered environmental policy, but such a dating is certainly open to debate, and varies much according to specific area, extent and country.
} 
is not economics which causes changes in the economy and society. The service of economists and their input are only then called for when there are problems in the economy and society, for which politicians do not find an easy answer. For this reason, not even the sign of the expected correlation is determined. Finally, a variable can simultaneously affect both economic science and society, so that a correlation is only seemingly causal.

These shortcomings are not to be taken lightly. They indicate that the aggregate production function for economics lacks a well specified theory. To overcome this problem makes it necessary to shift attention to the micro-basis of this relationship, i.e. to look at the process by which ideas are transformed into factors in the production function.

\section{B. The Influence of Economic Ideas}

\section{The Economic Consensus}

Are there typically "economic" ideas that deviate systematically from those of other sciences and lay persons and that are accepted by a majority of economists? A prominent US policy advisor, such as Schultze (1996: 26), is convinced: "There is a distinct consensus among economists". Recently, the so-called "Washington Consensus" (Williamson 1994) was praised for offering a "universal consensus" that summarizes "the common core of wisdom embraced by all serious economists" (see Middleton 1998: 344). Its major recommendation is that an active economic policy should fight microeconomic distortions, while safeguarding the macroeconomic equilibrium, in particular by balancing the state budget. That "economics (is) after all a science capable of truth and progress" (Williamson 1997: 365) is certainly not shared by all (serious) economists. Thus, Brittan (1995: 21) bluntly states: "The idea of technocratic value free economics has had its day". This is a view shared by, amongst others, Hirschman (1982), who observes that individualistic and collectivistic ideas and policy propositions follow fashion waves and cycles, rather than building up on a "truth" that had been previously established.

The extent of the consensus existing among professional economists has been the subject of several empirical studies ${ }^{3}$. They find some degree of consensus, but at the same time

\footnotetext{
${ }^{3}$ For the United Kingdom, Brittan 1973 and Machin and Oswald 1999; for the United States, Kearl, Pope, Whiting and Wimmer 1979, Alston, Kearl and Vaughan 1992; for several European countries including France, Germany, Austria and Switzerland, Frey, Pommerehne, Schneider and Gilbert 1984. Van Dalen and
} 
opinions often differ quite strongly. The dissent can partly be explained by historical and institutional differences. Thus, in the 80s, French and Austrian economists were much more inclined to welcome government interventions in the economy than were American, Swiss and German economists.

\section{The Source of Economic Ideas}

Economic ideas can originate from economists and non-economists, but also from think tanks, research institutes, scientific networks, foundations or private consultancy firms. At the outset, there is normally a contribution in the form of a publication, whose effect within the field is measured by the number of citations. A further source is academic teaching, from where the students transfer the knowledge into practical life (see section 3).

Economic ideas may also indirectly affect the economy and society via other fields. The extent of "economic imperialism" (Stigler 1984, Lazear 1999) is " ... an important indicator of success of economics" (Demsetz 1997: 1). The impact on political science is indeed strong (the number of citations to economic works has tripled between 1977/80 and 1988/90) as opposed to the impact on sociology where, after a considerable increase in the 1970s and 1980s, the 1990s saw now further increase in the number of citations (Baron and Hannan 1994).

\section{The Diffusion Process}

The path from economic ideas to the (possible) effect on the economy and society can be modeled in various ways (see also Coats and Colander 1989):

Frictionless transfer. A gap between economic ideas and their application for practical issues can well be overcome, provided the scientific content is brought forward in a language understood by non-economists (e.g. Hamilton 1992, Blendon et al. 1997). However, as Cordes, Klamer and Leonard (1993: 467) point out, the market to effect this transformation is not well developed. The gap cannot easily be bridged, as has been emphasized by the economic advisor Rivlin (1987: 1): "Economists and political leaders not only miscommunicate, but each accuses the other of incompetence, obfuscation, self- 
serving motives, and anti-social behavior". McCloskey (1983) and Klamer and Colander (1990) go even further when they argue that the discourse between economists and politicians totally differs, and is partly incompatible. While economists care about logic and elegance in formulations, political decision makers care about concrete answers to practical problems (Reder 1999: 309).

Automatic process. The transfer is like an epidemic whose course cannot be much altered and which expands towards an exogenously determined level of contagion. This mechanistic view is of little use, in particular because it does not answer the question which ideas are successfully diffused.

Information theory. Professional economists formulate economic ideas using their professional (linguistic) codes, which might or might not get interfered with by irrelevant and mistaken information. The recipients not trained in the language, such as politicians and bureaucrats, have to decode this information, which causes further misunderstandings. Market for economic ideas ${ }^{4}$. The suppliers - in addition to economic research institutes, scholarly networks, think tanks, foundations and profit-oriented consulting firms - offer economic knowledge, provided they have sufficient incentives in the form of material and immaterial rewards. Researchers at universities exposed to international competition have only a small incentive to deal with social problems of the day. What furthers their career is a formally advanced analysis of problems defined within the field itself, and assessed by their peers. As Colander (1989: 34) plainly states: "The incentives in the economics profession are for articles, not ideas".

The (potential) demanders of economic knowledge compare the expected benefits of the information with the cost of acquiring, processing and using it. The fact that politicians tend to be rather skeptical with respect to economic advice suggests that the benefit-cost ratio often is considered to be rather unfavorable.

The economic approach allows the diffusion process of economic ideas to be systematically analyzed by looking at the incentive structure of the actors involved, thereby establishing causal links, characterizing the equilibria reached and deducing empirically testable hypotheses. However, the research is only at its very beginning. It must, moreover, analyze the role of the media in the transfer process. The media pick up some economic ideas, especially when they are controversial (Rivlin 1987), yet suppress 
other economic ideas. But even when the media report, it remains an open question whether they succeed where the academic journals fail, namely putting economic knowledge into action.

\section{The Type of Ideas Transferred}

The natural response of most professional economists is to search for ways of manipulating the market mechanism (Nelson, 1987: 65). The notion of what is the "right" proposal has, however, drastically changed over the course of time. "Half a century ago, most economists were quick to favor government ownership of firms as soon as any market inequities or imperfections, such as monopoly power, were even suspected" (Shleifer 1998: 133-4). This view was proposed by some of the most prominent economists of that time, some of whom (Arthur Lewis, James Meade or Maurice Allais) later received the Nobel Prize in economics. These exponents of economics overlooked the "grotesque failure" of government firms and did not see what today is considered "right", namely " ... that private ownership is the crucial source of incentives to innovate and become efficient" (Schleifer 1998: 135) $)^{5}$.

"Typically economic" proposals (see Reder 1999, ch. 11) include institutions, such as the notion of an independent central bank, free trade, privatization or deregulation (the latter two are regarded as "success stories" by Nelson 1987). Proposals also include policy measures, such as market-based environmental instruments, vouchers, the negative income tax, road pricing and peak load pricing (Faulhaber and Baumol 1988), pay for performance, stock options (e.g. Prendergast 1999), or auction rules for the allocation of, for example, radio and TV frequencies (e.g. Joskow, Schmalensee and Bailey 1998). Yet, even in this case, the overall performance needs to take into account misguided research effort, which accompanied the so-called success stories, Thus, for instance, Blinder (1997: 17), a former vice president of the Federal Reserve, complains that " ... theorists have lavished vastly too much attention on a nonexistent time-inconsistency problem while ignoring a much more real problem that arises when central bankers 'follow the market' too closely".

\footnotetext{
${ }^{4}$ See, more extensively, Middleton (1998) for the United Kingdom and, in general, Frey and Eichenberger (1992, 1993, 1997).

${ }^{5}$ It might be asked why Schleifer knows so definitely what the truth is. Might it not happen that future generations of economists will consider his statement with similar scorn?
} 
There are only a few impressionistic studies describing the transfer process from economic ideas to political decision making. The conclusions are disheartening. For example, Galbraith (1988: 224) reports: "Council of Economic Advisors (CEA) Chairman Murray Weidenbaum, when asked what weight of influence, on a scale of one to ten, economists had enjoyed in drafting the original tax program of the (Reagan) administration, replied, 'Zero' ". Aaron (1987: 7) speaks of the American tax reform of 1986 under President Bush as a "frustrating situation" because the leading economists completely differed with respect to the expected effects on efficiency and distribution. Cordes, Klamer and Leonard (1993) also find that the influence of economic ideas was only minor. They even propose that economists may have had some influence, but not economics. Concerning the establishment of NAFTA, Klamer and Meehan (1999: 1) conclude: " ... political arguments crowd out serious economic arguments ... academic economists had no role to play when it came to the final act". Similar views are aired by Cassidy (1996, see also Krugman 1995) with respect to the reform of the American health and welfare system.

Most observers agree that only simple economic ideas may exert influence on the political process. Thus Blinder (1997: 18) speaks of "trained common sense", Stein, a former chairman of the Council of Economic Advisors, believes that "most of the economics that is usable for advising on public policy is about the level of the introductory undergraduate course", and Reder (1999: 18) concludes that "often the on-the-job performance of broadly educated economists surpasses that of otherwise comparable economists with superior technical training, but less general knowledge." It is worth noting that already Marshall (1890, 1936: 779) reported a similar experience a hundred years earlier.

\section{The Influence of Economists as Persons}

The influence on the economy and society of economists as persons can be understood in terms of a market ${ }^{6}$. I first consider supply and demand, where the income of economists is assumed to reflect the equilibrium.

\footnotetext{
${ }^{6}$ But as Hansen (1999: 147) notes, the market for economists has rarely been analyzed by economists.
} 


\section{Supply}

Economists can directly influence society in their role of practitioners, while working in their profession within companies. They are employed in public administration (see Coats 1981, 1989), in international organizations (Coats 1986), and in public or private research institutes (e.g. Cockett 1995). Finally, they can turn entrepreneurial by establishing consultancy companies, a sector which recently experienced "explosive growth" in the USA and elsewhere (Mandel 1999: 115). There are also many economists who have achieved distinguished positions in politics (see the Appendix). Further influence can be expected when economists serve as advisers in public institutions, such as the German Sachverständigenrat or the US Council of Economic Advisors (see, recently, Stein 1996, Schultze 1996, Feldstein 1997, Stiglitz 1997), or other academic advisory boards attached to ministries. Despite this impressive list of occupations, Wyplosz (1999: 54) doubts the economists' ability to make an impact on the ground that "the field of policy advice draws some of the best, but also some of the worst, academic economists".

Academic economists can also have an indirect effect with their teaching and research activities, thus shaping the knowledge of a future generation of economists.

The various activities just mentioned can fundamentally differ according to expectations. On the one side, economists are expected to act as "impartial representatives of the social good"; on the other side, they are called to help one of the parties involved to win an argument. Economic experts in law cases well illustrate the point. The rapid growth of forensic economics ${ }^{7}$ started with the wave of takeovers or mergers of firms, as well as with the policy of deregulation and privatization in the public sector. A "bias" in economic advice in litigation can be expected when economic experts are remunerated according to success in court (Thornton and Ward 1999). But there are clear limits to this tendency, (Posner 1999) so long as the market acknowledges professional competence and impartiality. Another limit to moral hazard is defined by the other party's interest, which results in a close scrutiny of the arguments offered. Due to the high monetary consequences involved, this critique tends to be even more intensive than is the case with journal referees (Posner 1999). And yet, these limits might not be enough to safeguard "good economic reasoning". When both parties in the law case use economists from the same school, i.e. those who share the same paradigm, then the exchange of arguments will 
be highly parsimonic, to the detriment of the judges or the general public, who will find it hard to follow the logic. One example of this kind of a problem is offered in the design of an auction system in US telecommunication (Reder 1999, 281-284). Other negative aspects of forensic activity lie in the fact that the data used are not normally available to the scientific community, which hinders progress, and in the lock-in effect of scholars, who find it costly to change a position once taken.

A utility maximizing academic economist compares the marginal benefits and cost of the various activities. His or her incentives to directly influence the economy and society are the material compensation and the immaterial benefits in terms of recognition, status and power, but also the intrinsic rewards derived from the activity itself. Forensic advising is well paid, not least due to the superstar-effect (Rosen 1981, Frank 1985). The incentives to work in scientific advisory boards mainly consist in the reputation and a certain prominence gained. For persons who seriously embark on an academic career, these incentives are only weak or even negative (Frey and Eichenberger 1993, the special issue of Kyklos edited by R.L. Frey and B.S. Frey 1995). All the time available and all the work capacity must be devoted to publishing in good journals and to being cited as often as possible. As long as academic journals honor formal theoretical arguments more then robust theories which survive empirical scrutiny, economists will find it hard to combine both striving for academic excellency and contributing to the solutions of day to day economic problems.

\section{Demand}

The demand for economists is most clearly visible at the university level. In the United States, the number of students taking economics as a major dropped drastically by 30 percent between 1992 and 1996, while the number of doctoral students fell by 18 percent in the same time (Siegfried 1998). Moreover, a considerable share of American PhD graduates in economics leaves the country later (Siegfried and Stock 1999: 116-8), indicating an even more drastic decline of US American students embarking on a $\mathrm{PhD}$ program. This interpretation is also supported by the fact that many, if not most, $\mathrm{PhD}$ programs at American universities rely on foreign participants for their survival. The

\footnotetext{
${ }^{7}$ According to Mandel (1999: 115), turnover " ... by the scale of academic economics ... is an enormous amount ... it is almost certainly larger than the payroll for the full-time faculty of the top 25 economics departments".
} 
United Kingdom (Middleton 1998: 360, Machin and Oswald 1999) faces a similar problem. In German universities, economic departments are threatened by the lack of students, while the less theory-driven departments in business economics flourish. Quite generally, a degree in economics is no longer regarded as particularly useful by the potential demanders - at least if the high effort required is taken into account.

In short, to teach or do research in economics seems to have lost its appeal. There is also reason to believe that the most talented young students no longer see general economics as an option. Instead, they move toward a specialization in finance, labor and resource economics, with the intention of finding a job outside academia. In the US for example, the share of economists employed by the private sector increased by not less than 70 percent over the last decade (Siegfried and Stock 1999: 129-33). All this indicates that the demanders no longer consider a degree in general economics to be sufficient for a practical career (see also Krueger 1999 and the reports to the American Economic Association and the Royal Economic Society by Krueger et al. 1991 and by Towse and Blaug 1988, respectively). It has even been claimed that, after their university education, economists must be "cleansed" (Cassidy 1996) or "reprogrammed" (Nelson 1987) for up to three or four years after graduation. This corresponds with the evaluation by $\mathrm{PhD}$ students in economics. Just 3 percent (!) of American graduates consider a thorough knowledge of the economy as crucial for their exams, as opposed to 57 percent who regard an excellent knowledge in mathematics as decisive. A further 65 percent think that the ability to solve formal problems (Colander and Klamer 1987: 100; see also more recently van Dalen and Klamer 1997 for the Netherlands) is crucial. And yet, little has been done in the economics departments to change this situation and to adjust the undergraduate and graduate education. Not surprisingly, students of economics are increasingly dissatisfied with their field (Siegfried and Stock 1999: 130 for the USA) to the effect that "business and public policy schools ... begin training their own PhDs rather than drawing heavily on the output of economics departments" (Krueger 1999: 155).

In order to get a broader perspective, two determinants of the demand side for an education in economics deserves more attention.

First, the demand for economists is partly produced by economics itself. For example, economic theories which favor government intervention increase the demand for economists in public advisory boards and within the public administration. According to Friedman (1986: 8-9), one reason why Keynesian theory became so quickly accepted was 
that " ... it opened up such wonderful opportunities for employment and influence by economists ... the New Deal was the greatest employment program for economists that ever existed". In the 80s, the policy of privatization and deregulation increased the demand for economists in the private sector.

Second, the equilibrium in the market for economists is strongly determined by political influences, so long as a considerable share of economists is active in the public sector. This phenomenon calls for a "Political Economy of Advising" 8 instead of assuming a wellfunctioning labor market. The politicians are mainly driven by their determination to remain in power. In an authoritarian state, politicians call for advice which supports their views, irrespective of whether it benefits or damages social welfare or whether the advice is "sound economics". Well functioning democracies are not much better when it comes to catching the attention of politicians. Politicians, in this case, have an incentive to accommodate the expectations of their constituencies rather then follow unpopular economic advice. In any case, the politicians expect advice to be useful for themselves and will reject advice that they regard as detrimental to their re-election chances.

\section{Incomes}

In general, market prices and incomes of those offering a service reflect the individual propensity to pay for the service. The market price therefore reveals the evaluation of an activity by society. This is a truism in a well-functioning market where external effects or monopolistic structures are missing. In the case of the market for economists in the private sector, or the market for forensic economists, the necessary conditions are likely to be met ${ }^{9}:$ " ... the ability to command large sums for economic expertise helps provide a market-based validation of the worth of studying economics" (Mandel 1999: 116).

On the other hand, it is hard to reconcile today's university system with the concept of a well-functioning market. Entry is limited, positive externalities are (hopefully) produced, and prices and incomes are fixed by administrative rules. The incomes of academics therefore do not, or only imperfectly, reflect the evaluation of economics by society. Only those universities which can adjust come close to fit into a market situation, as they have to

\footnotetext{
${ }^{8}$ See e.g. Blankart 1981, Peacock 1988, 1991, 1992, 1994, Jones and Cullis 1993, Kirchgässner 1999.

${ }^{9}$ As discussed above, forensic economic activities may produce some external effects. It at least partly boils down to a pure distributional struggle between the parties involved. Because of the high intellectual and material resources invested, conceivably a negative sum is produced.
} 
take into account the salaries offered by the competing private sector. It is therefore useful to look at the situation in the United States. Real average incomes of PhDs in economics dropped by 4.6 percent in the period 1987-95, despite the fact that the length of education had increased by 6 percent in the same time. In other words, the rate of return on human capital has continuously dropped since 1987 (Siegfried and Stock 1999: 132). That the rate

of return did not only decrease over time, but also with regard to neighboring fields, can be seen by the fact that the income shortfall of PhDs of first-rate economic university departments, compared to graduates of law or business schools (in MBA-programs), is large and increasing. The income differential also widened if economists are compared with other qualified professionals, among them persons in entertainment, sports, and managers of large enterprises (Ehrenberg 1999: 137-40).

\section{Strength of Influence}

Under what conditions are economists able to exert the strongest influence? It is possible to isolate some conditions whose actual influence may be empirically tested:

(a) A Zeitgeist, trends, theories and ideologies directed against the market and favoring government intervention, give economists more scope for activity and influence. The planning euphoria after WWII and Keynesianism are cases in point. The same also applies for periods of deregulation and privatization for which economists - but even more lawyers - are required. But, once this phase is over, the demand for economists is bound to drop.

(b) A legalistic-interventionist type of state favors technocrats with an education in general economics. France, as well as many South-American countries, can be assumed to serve as examples.

(c) Bad economic conditions support economists' role. because more government intervention is demanded and executed.

(d) In situations of fundamental uncertainty (Siegenthaler 1993), such as in Germany after 1945 and in many former Soviet economies after 1989, individuals seek to be guided by science and, in particular, by economics. This opens possibilities for activities and 
employment for economists. But, at the same time, this also increases the demand for esoteric solutions, to which economists have nothing to contribute.

\section{An Evaluation}

How strongly does economics influence the economy and society? The discussion so far does not convey a clear picture. Some will draw the conclusion that economics after all has a strong effect, while others are more skeptical or even deny any influence. For this reason, I allow myself at the end to give an evaluation from my personal point of view based on the impressions gained while collecting the evidence presented.

\section{A. Limited Knowledge}

Many contributions to the subject are based on mere assertions, speculations and wishful thinking. Empirical "evidence" often takes the form of selected, non-representative events which, moreover, are often presented in anecdotal form. Convincing empirical evidence on the effect on the economy and society of economics is missing.

This contribution points to the gap of knowledge and suggests establishing the "economics of economics" as an accepted field of inquiry. But not only empirical evidence is needed; foremost the difficult area must be subjected to rigorous analytical analysis.

\section{B. Has Economics Given Up Economic Policy?}

Economics has increasingly become the analysis of formal and self-defined problems within a closed academic field. Economics tends not to be used in order to meet the challenges posed by reality, but to engage in an academic discourse following accepted intellectual standards. No contribution to economic policy is intended. The question posed here about the social influence of economics is neither seen nor considered to be relevant. From this point of view, the formalism of economics can be seen as an instrument for the selection of contenders for an academic career. Mastering the formal instruments of modern economics provides the signal, showing that the corresponding person is capable of academic teaching and masters the research techniques deemed necessary by the profession. Only then can she or he become a member of the guild. The difficult-to-acquire 
entrance price demands similar intellectual abilities to the contenders for a bureaucratic career in imperial China who had to show that they were able to write poems considered to be beautiful. Similarly, the knowledge of a dead language, Latin, was taken to be the signal of a cultured person way into the 20 th century.

This particular view of economics does not apply to the whole field. But it would be difficult to deny that this interpretation of economics occupies an increasing share of economics, and has the highest prestige ${ }^{10}$. The consequences for young academics and for the selection of professorial posts is clearly visible.

\section{Which Direction Is Economics Heading In?}

An economics increasingly focussing on self-defined problems, only faintly related to real world issues, is confronted with serious difficulties, which are likely to become more severe over the course of time:

First of all, the proportion of students at all levels studying economics is likely to fall further, in particular relative to management, but also relative to other fields. The question arises whether our field is still attractive to the best young people. Until recently, very motivated and gifted young persons chose to study economics because they wanted to contribute to solving pressing social problems such as unemployment, poverty or environmental pollution. This incentive gets lost when the discipline is mainly or wholly concerned with internal puzzles.

As a consequence, resources in the form of chairs, assistants, researchers and administrative personnel get lost. Economics might become a (rather unimportant) part of applied mathematics. Such a resource loss has to be taken particularly seriously by a subject which accepts market evaluations.

Finally, economics loses its importance in the media, especially with respect to issues of economic policy, but also more generally in the social discourse.

\footnotetext{
${ }^{10}$ A simple test supports this statement: how often, in an academic seminar or in a referee report, have you seen the argument, that the idea should be presented in a more rigorous, i.e. more formal, manner and how often have you heard the argument that more knowledge of history or of sociology is required?
} 


\section{Where Will the Challenges Posed by Society Be Economically Analyzed?}

Consulting the journals in our field, one regularly comes across excellent problem oriented contributions. The respective authors at least attempt to influence the economy and society. But at the same time, it is necessary to note that economic problems are more and more dealt with in academic areas outside economics. Increasingly, one finds particularly important contributions in business administration, law, geography, sociology, political science or public policy. Accordingly, the corresponding education is undertaken in these fields.

In addition, an increasing, and today already sizeable, share of problem oriented research is undertaken in profit oriented or in non-profit research networks. They are located outside the universities, and the connection to academic teaching tends to be lost.

Finally, there is a strong trend to an "everyday economics" used by journalists, politicians, public administrators and persons managing the media. The respective books quite often result in best-sellers read by millions of persons. This kind of economics is far from the discourse dominating our field today: the formally oriented scholars with the highest reputation within the field are often virtually speechless. This, in turn, strengthens views which are far from the teaching and research of academic economics.

The various consequences discussed are irrelevant to those economists who do not believe that economics should endeavor to meet the challenges posed by social problems.

However, for others - among them the present author - the prospects look undesirable. 


\section{Appendix: Political Positions of Economists (state: mid-1999)}

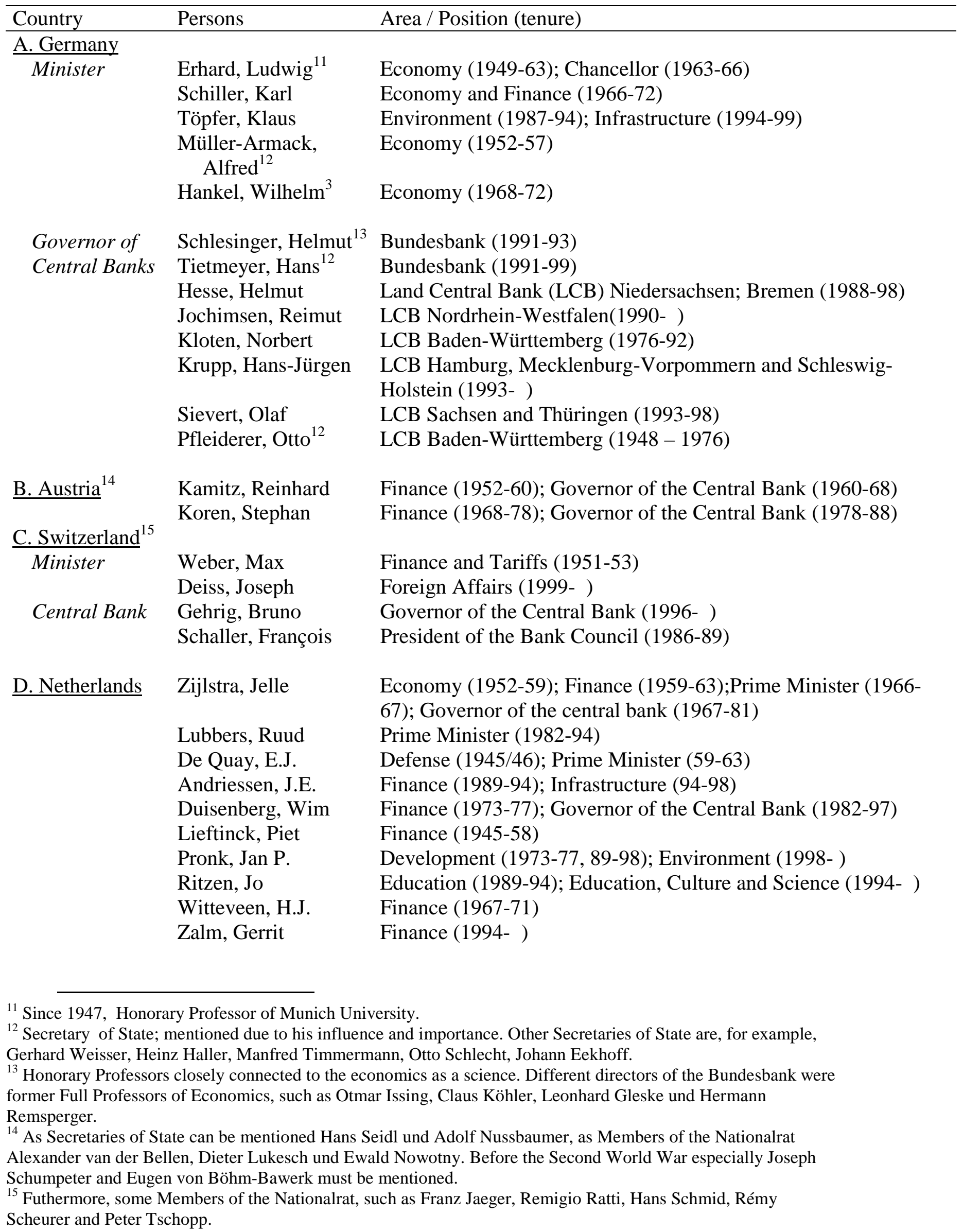


E. Belgium

G. Denmark
Finance (1980/81; 81-88); Prime Minister (1981)

Economy (1950-51); Infrastructure (1950-52)

Health (1966-68)

Hulpiau, Raphaël

Van Offelen, Jacques

Simonet, Henri

Economy (1958-60); Industry/Trade (1960-61)

Economy (1972); Foreign Affairs (1977-80)

Finance (1980); Prime Minister (1985-95)

Prime Minister (1932-68)

Finance (1955-65); Governor of the Central Bank

António

Beleza, Miguel Finance; Governor of the Central Bank

Braga de Macedo, Finance (1991Jorge

Mateus, Augusto $\quad$ Economy (1996-97)

Moura Pína, Joaquim Economy (1997- )

Lopes, Ernâni

Finance (1983-85)

Lopes da Silva, José $\quad$ Finance $(1974-75 ; 1978)$

Nunes, Jacinto

Finance (1978-79); Economy; Governor of the Central Bank

Pereira de Moura, Economy (1975)

Francisco

Salgueiro, João

Finance (1981-83)

Economy (1968-71; 73- )

Finance (1945-47)

Housing

Trade (1957-60); Finance (1960-65)

$\underline{\text { H. Other Countries: Some remarkable persons }}^{17}$

\begin{tabular}{|c|c|c|}
\hline \multirow[t]{7}{*}{ Italy } & Einaudi, Luigi & Finance (1945-48); Italian President (1948-55) \\
\hline & Fanfani, Amintore & Domestic Affairs (1953-54); Prime Minister (1958-59) \\
\hline & Prodi, Romano & Prime Minister (1996-99) \\
\hline & Forte, Francesco & $\begin{array}{l}\text { Finance (1982-83); European Affairs (83-85); Development } \\
\text { (85-87) }\end{array}$ \\
\hline & Martino, Antonio & Foreign Affairs (1994-95) \\
\hline & Reviglio, Franco & Finance (1992-93) \\
\hline & Spaventa, Luigi & Finance (1993-94) \\
\hline \multirow{3}{*}{$\begin{array}{l}\text { United } \\
\text { Kingdom }^{18}\end{array}$} & Wilson, Harold & Prime Minister (1964-70; 1974-76) \\
\hline & Dalton, Hugh & $\begin{array}{l}\text { War (1940-42); Trade (1942-45); Finance (1945-47); } \\
\text { Planing (1950-51) }\end{array}$ \\
\hline & Gaitskell, Hugh & $\begin{array}{l}\text { Combustibles (1947-50); Finance (1950-51), } \\
\text { Leader of the Opposition (1955-63) }\end{array}$ \\
\hline
\end{tabular}

\footnotetext{
${ }^{16}$ Professor of Law and Public Finance (not for economics).

${ }^{17}$ Either Incumbent of high positions or well-known Scientists.

${ }^{18}$ Members of the House of Lords who are (were) academic economists but not professors: Thomas Balogh, Peter Bauer, Meghnad Desai, Richard Kahn, Nicholas Kaldor, John Maynard Keynes, Lionel Robbins. The Monetary Policy Committee of the Bank of England presently consists mainly of professors: Mervyn King (Deputy Governor), John Vickers (Executive-Director; previously John Flemming), Sir Alan Budd, Willem Buiter, Charles Goodhart.
} 
Jay, Douglas

United States

of America

Israel

France

Greece

Turkey

Polish Republic

Lange, Oskar

Balcerowicz, Leszek

Sweden

Czechoslovakia

/Czech

Republic

Argentina Cavallo, Domingo

$\underline{\text { I. International }}$

European

Commission

Delors, Jacques

Prodi, Romano

Monti, Mario

European Duisenberg, Wim

Central Bank Issing, Otmar

European Nowotny, Ewald

Investment

Bank
Trade (1964-67); President of the Board of Trade

President of the Federal Reserve (1970-77)

Vice President of the Federal Reserve (1994-96)

Board of Governors, Fed. Res. (1974- )

Labor (1968-70); Finance (1972-74); Foreign Affairs (198289)

Governor of the Bank of Israel (1986-91)

Governor of the Bank of Israel (1991- )

Prime Minister (1976-81)

Industry (1991-93); Economy (1997-99)

Prime Minister (1981-89; 1993-96)

Prime Minister (1993-96)

Vice President

Finance and Deputy Prime Minister (1989-91)

Trade (1944-45)

Trade (1945-47)

Economy and Deputy Prime Minister (1968)

Finance (1989-92); Prime Minister (1992-97)

Economy (1991-96)

President (1985-94)

President (1999- )

Commissioner (1995- )

President (1998- )

Member of the board of directors (1998- )

Vice President (1999- )

First Deputy Director, IMF (1994- )

Senior Vice President, World Bank (1997-99) 


\section{References}

Aaron, Henry J. (1987). Symposium on Tax Reform. Economic Perspectives 1 (1), 7-10.

Acs, Zoltan J., David B. Audretsch and Maryann P. Feldman (1991). Real Effects of Academic Research: Comment. American Economic Review 82 (1), 363-367.

Allen, G.C. (1979). The British Disease: a short essay on the nature and causes of the nation's lagging wealth. 2nd, London, IEA.

Alston, R.M., J.R. Kearl and M.B. Vaughan (1992). Is there a consensus among economists in the 1990s? American Economic Review 82 (2, Papers \& Proceedings), 203-209.

Baron, James N. and Michael T. Hannan (1994). The Impact of Economics on Contemporary Sociology. In: Richard Swedberg (ed.). Economic Sociology. Cheltenham, Elgar, 530-65.

Barro, R.J. (1993). Council of economic irrelevance. Wall Street Journal.

Becker, Gary S. (1985). Public policies, pressure groups, and dead weight costs. Journal of Public Economics 28, 371-400.

Blankart, Charles B. (1981). Towards an Economic Theory of Advice and Its Application to the Deregulation Issue. Kyklos 34, 95-105.

Blaug, Mark (1997). Ugly Currents in Modern Economics. Fact or Fiction? Conference on Realism in Economics, Rotterdam, 14-15 November.

Blendon, Robert J., John M. Benson et al. (1997). Bridging the Gap Between the Public's and Economists' View of the Economy. Journal of Economic Perspectives 11 (3), 105118.

Blinder, Alan S. (1997). Distinguished Lecture on Economics in Government: What Central Bankers Could Learn from Academics - and Vice Versa. Journal of Economic Perspectives 11 (2), 3-19.

Bommer, Rolf and Heinrich W. Ursprung (1998). Spieglein, Spieglein an der Wand. Eine publikationsanalytische Erfassung der Forschungsleistungen volkswirtschaftlicher Fachbereiche in Deutschland, Österreich und der Schweiz. Zeitschrift für Wirtschaftsund Sozialwissenschaften 118 (1), 1-28.

Bonus, Holger (1982). Information und Emotion in der Politikberatung - Zur politischen Umsetzung eines wirtschaftstheoretischen Konzepts. Zeitschrift für die gesamte Staatswissenschaft 138, 1-21.

Borner, Silvio (1975). Wissenschaftliche Ökonomik und politische Aktion: Eine Politische Ökonomie der professionellen Beratung der Wirtschaftspolitik. Bern, Haupt.

Brittan, S. (1973). Is there an Economic Consensus?: an Attitude Survey. London, Macmillan.

Brittan, S. (1995). Economics and Ethics. In: S. Brittan and A. Hamlin (eds.). Market Capitalism and Moral Values. Aldershot, Edward Elgar, 1-22.

Carter, J. and M. Irons (1991). Are Economists Different, and if so, Why? Journal of Economic Perspectives 5, 171-177.

Cassidy, J. (1996). The Decline of Economics. New Yorker, 2. December, 50-60.

Clower, Robert W. (1989). The State of Economics: Hopeless but not Serious? In: David Colander and A.W. Coats (eds.). The Spread of Economic Ideas. Cambridge, Cambridge University Press, 23-41.

Coase, Ronald H. (1999). Economists and Public Policy. In: Daniel B. Klein (ed.). What Do Economists Contribute? New York, New York University Press, 33-52.

Coats, Alfres W. (1981). Economists in Government: An International Comparative Study. Durham, N.C., Duke University Press.

Coats, Alfred W. (1986). Economists in International Agencies: An Exploratory Study.

New York, Praeger. 
Coats, Alfred W. (1989). Economic Ideas and Economists in Government:

Accomplishments and Frustrations. In: David C. Colander and A. W. Coats (eds.). The

Spread of Economic Ideas. Cambridge, Cambridge University Press, 109-118.

Coats, Alfred W. and David C. Colander (1989). An introduction to the spread of economic ideas. In: David C. Colander and A. W. Coats (eds.). The Spread of Economic Ideas. Cambridge, Cambridge University Press, 1-19.

Cockett, Richard (1995). Thinking the Unthinkable. Think Tanks and the Economic Counterrevolution 1931-1983. London: Harper Collins.

Colander, David and Arjo Klamer (1987). The Making of an Economist. Journal of Economic Perspectives 1 (2), 95-111.

Colander, David C. (1989). The invisible hand of truth. In: Colander David C. and A. W. Coats (eds.). The Spread of Economic Ideas. Cambridge, Cambridge University Press, 31-36.

Cordes, Joseph J., Arjo Klamer and Thomas C. Leonard (1993). Academic Rhetoric in the Policy Arena: The Case of Capital Gains Taxation. Eastern Economic Journal 19 (4), 459-479.

Dalen, Harry P. van and Arjo Klamer (1997). Blood is Thicker than Water: Economists and the Tinbergen Legacy. In: Peter A.G. van Bergeijk, A. Lans Bovenberg, Eric E.C. van Damme and Jarig van Sinderen (eds.). Economic Science and Pratice: The Roles of Academic Economists and Policy-makers. Cheltenham, Edward Elgar, 60-91.

Demsetz, H. (1997). The primacy of economics: an explanation of the comparative success of economics in the social sciences. Economic Inquiry 35 (1), 1-11.

Economist (1997). The Puzzling Failure of Economics. 23rd August 1997, 13.

Ehrenberg, Ronald G. (1999). The Changing Distribution of New Ph.D. Economists and Their Employment: Implications for the Future. Journal of Economic Perspectives 13 (3), 135-138.

Eichenberger, Reiner, Rolf Arpagaus und Ursina Meier (1999). Ökonomen, Publikationen und Zitationen: Ein europäischer Vergleich. Jahrestagung der Schweizerischen Gesellschaft für Statistik und Volkswirtschaft, 25. und 26. März, Fribourg.

Faulhaber, Gerald R. and William Baumol (1988). Economists as Innovators. Journal of Economic Literature 26 (2), 577-600.

Feldstein, Martin (1997). The Council of Economic Advisers: From Stabilization to Resource Allocation. American Economic Review 87 (2), 99-106.

Frank, Robert H. and Philip J. Cook (1995). The Winner-Take-All Society. New York, Free Press.

Frank, Robert H., Thomas D. Gilovich and Dennis R. Regan (1993). Does Studying Economics Inhibit Cooperation? Journal of Economic Perspectives 7, 159-171.

Frey, Bruno S. and Reiner Eichenberger (1992). Economics and Economists: A European Perspective. American Economic Review 82 (May), 216-220.

Frey, Bruno S. and Reiner Eichenberger (1993). American and European Economics and Economists. Journal of Economic Perspectives 9 (1) (Winter), 203-212.

Frey, Bruno S. and Reiner Eichenberger (1997). Economists: First Semester, High Flyers, and UFOs. In: Peter A. G. van Bergejik, A. Lans Bovenberg, Eric E. C. Van Damme and Jarig van Sinderen (eds.). Economic Science and Practice: The Roles of Academic Economists and Policy-makers. Cheltenham, UK and Brookfield, USA, Edward Elgar, $15-48$.

Frey, Bruno S. and Gebhard Kirchgässner (1994). Demokratische Wirtschaftspolitik. München, Vahlen.

Frey, Bruno S., Werner W. Pommerehne and Beat W. Gygi (1993). Economics Indoctrination or Selection? Some Empirical Results. Journal of Economic Education 24 (3), 271-281. 
Frey, Bruno S., W.W. Pommerehne, F. Schneider and G. Gilbert (1984). Consensus and dissension among economists: an empirical inquiry. American Economic Review 74 (5), 986-994.

Frey, Bruno S. and Alois Stutzer (2000). Happiness, Economy and Institutions. Economic Journal forthcoming.

Frey, René L. (1996). Ökonomie und Politik: Über die Schwierigkeit der Wirtschaftspolitischen Beratung. Rektoratsrede; Basler Universitätsreden 29. Heft. Basel, Helbing \& Lichtenhahn.

Frey, René L. and Bruno S. Frey (1995). Is there a European Economics? Kyklos 48 (Special Issue), 187-311.

Friedman, Milton (1972). Have monetary policies failed? American Economic Review 62 (2, Papers \& Proceedings), 11-18.

Friedman, Milton (1986). Economists and Economic Policy. Economic Inquiry 14 (January), 1-10.

Fuchs, Victor R., Alan B. Krueger and James M. Poterba (1997). Why do economists disagree about policy? The roles of beliefs about parameters and values, NBER Working Paper No. 6151.

Gäfgen, G. (1976). Politische Ökonomie und Lehre von der Wirtschaftspolitik: Zur Realisierung wirtschaftspolitischer Vorschläge. In: H. Körner, P. Meyer-Dohm, E. Tuchtfeld and C. Uhlig (eds.). Wirtschaftspolitik - Wissenschaft und politische Aufgabe. Bern / Stuttgart, 123-143.

Galbraith, James (1988). The Grammar of Political Economy. In: Arjo Klamer, D. McCloskey and R. Solow (eds.). The Consequences of Economic Rhetorik. New York, Cambridge University Press, 221-39.

Galbraith, J.K. (1975). Letter. The Times, 12.

Hahn, F.H. (1985). In praise of economic theory. London, University College London.

Hamilton, L.H. (1992). Economists as Public Policy Advisers. Journal of Economic Perspectives 6 (Summer), 61-64.

Hansen, J. Lee (1999). The Link from Graduate Education in Economics to the Labor Market. Journal of Economic Perspectives 13 (3), 147-152.

Hayek, Friedrich A. (1991). On Being an Economist. In: W.W. Bartley and Stephen Kresge (eds.). The Trend of Economic History. Chicago, University of Chicago Press, $35-48$.

Hirschman, Albert O. (1982). Shifting Involvements. Private Interests and Public Action. Oxford, Martin Robertson.

Jaffe, Adam B. (1989). Real Effects of Academic Research. American Economic Review 79 (5), 957-970.

Jöhr, Walter A. and Hans W. Singer (1955). The Role of the Economist as Official Advisor. London, Allen and Unwin.

Jones, Philip R. and John G. Cullis (1993). Public choice and public policy: The vulnerability of economic advice to the interpretation of politicians. Public Choice 75 , 63-77.

Joskow, Paul L., Richard Schmalensee and Elisabeth M. Bailey (1998). The Market for Sulfur Dioxide Emissions. American Economic Review 88 (4), 669-685.

Kearl, J.R., C.L. Pope, B.C. Whiting and L.T. Wimmer (1979). A confusion of economists? American Economic Review, Papers \& Proceedings 69 (2), 28-37.

Keynes, J. M. (1936). The General Theory of Employment Interest and Money. London, Macmillan.

Kirchgässner, Gebhard (1993). Vom Nutzen der Wirtschaftstheorie für die Wirtschaftspolitik. Konjunkturpolitik 39, 201-225. 
Kirchgässner, Gebhard (1996). Ideologie und Information in der Politikberatung: Einige Bemerkungen und ein Fallbeispiel. Hamburger Jahrbuch für Wirtschafts- und Gesellschaftspolitik 41, 11-41.

Kirchgässner, Gebhard (1998). Wirtschaftspolitische Beratung aus der Sicht des kritischen Rationalismus: vierzehn Thesen. Karl Poppers kritischer Rationalismus, Gummersbach.

Kirchgässner, Gebhard (1999). On the political economy of policy advice. In: Ernst Mohr (ed.). The transfer of economic knowledge. Cheltenham, Edward Elgar, 13-31.

Klamer, Arjo and David Colander (1989). The Making of an Economist. Boulder, Col., Westview Press.

Klamer, Arjo and Jennifer Meehan (Forthcoming). The crowding out of academic economics: The case of Nafta. Mimeo, Dept. of Economics, University of Rotterdam.

Klein, Daniel B. (ed.) (1999). What do Economists Contribute? New York, New York University Press.

König, Heinz (1999). Economic knowledge transfer by research institutes in Germany: some reflections. In: Ernst Mohr (ed.). The transfer of economic knowledge. Cheltenham, Edward Elgar, 90-99.

Krueger, Anne O. (1999). Implications of the Labor Market for Graduate Education in Economics. Journal of Economic Perspectives 13 (3), 153-156.

Krueger, Anne O. et al. (1991). Report of the Commission on Graduate Education in Economics. Journal of Economic Literature 29 (3), 1035-1053.

Krugman, Paul (1996). Pop internationalism. Cambridge, MA, MIT Press.

Krugman, Paul R. (1995). Incidents from my Career. In: Arnold Heertje (ed.). The Makers of Modern Economics. Vol. 2. Aldershot UK, Edward Elgar.

Laband, David N. and Richard O. Beil (1999). Are economists more selfish than other 'social' scientists? Public Choice 100 (1-2), 85-101.

Leontief, W. (1971). Theoretical Assumptions and Nonobserved Facts. American Economic Journal 61 (1), 1-7.

Machin, Stephen and Anrew Oswald (1999). Signs of Disintegration: A Report on UK Economics PhD. and ESRC Studentship Demand. Report commissioned by the Economics and Social Research Council. Revision III- June.

Magee, Stephen P. (1992). The Optimum Number of Lawyers: A Reply to Epp. Law and Social Inquiry 17, 667-93.

Mandel, Michael J. (1999). Going for the Gold: Economists as Expert Witnesses. Journal of Economic Perspectives 13 (2), 113-120.

Marshall, Alfred (1890). The Principles of Economics. 8th. edn. (1920), London, Mcmillan.

Mayer, Thomas (1993). Truth versus Precision in Economics. Aldershot, Edward Elgar.

McCloskey, Donald (1983). The Rhetoric of Economics. Journal of Economic Literature (June), 481-547.

Meier, Alfred and Daniel Mettler (1988). Theorie der Wirtschaftspolitik und Wirtschaftspolitische Beratung. In: Praxisorientierte Volkswirtschaftslehre. Bern, Stämpfli.

Meier, Ursina B. (1994). Wissenschaftliche Publikationsaktivitäten an Hochschulen - ein Vergleich der volkswirtschaftlichen Abteilungen deutschweizer Hochschulen. Schweiz. Zeitschrift für Volkswirtschaft und Statistik 130 (2), 207-232.

Middleton, Roger (1998). Charlatans or Saviours? Economists and the British economy from Marshall to Meade. Northhampton MA, Edward Elgar Publisher.

Nelson, R.H. (1987). The economics profession and the making of public policy. Journal of Economic Literature 25 (1), 49-91.

Peacock, A. T. (1988). An economic analysis of economic advice-giving. Atlantic Economic Journal 16 (3), 1-10. 
Peacock, A. T. (1991). Economic advice and economic policy. In: D. Greenaway, M. Bleaney and I.M.T. Stewart (Eds.). Companion to contemporary economic thought. London, Routledge, 713-716.

Peacock, Alan T. (1992). The credibility of economic advice to government. Economic Journal 102 (5), 1213-1222.

Peacock, A.T. (1994). The Utility Maximizing Government Economic Adviser: a Comment. Public Choice 80 (1), 191-197.

Peters, Guy and Anthony Barker (1993). Advising West European Gevernments: Inquiries, Expertise and Public Policy. Edinburgh, Edinburgh University Press.

Pommerehne, Werner W., Friedrich Schneider, Guy Gilbert and Bruno S. Frey (1984). Concordia Discors: Or: What do Economists Think? Theory and Decision 16, 251-308.

Posner, Richard A. (1999). The Law and Economics of the Economic Expert Witness. Journal of Economic Perspectives 13 (2), 91-100.

Prendergast, Canice (1999). The Provision of Incentives in Firms. Journal of Economic Perspectives 37 (1), 7-63.

Reder, M.W. (1999). Economics. The Culture of a Controversial Science. Chicago and London, University of Chicago Press.

Rivlin, A. (1987). Economics and the Political Process. American Economic Review 77 (1), $1-10$.

Samuels, Warren J. (1980). Economics as a Science and Its Relation to Policy: The Example of Free Trade. Journal of Economic Issues 14 (March), 163-85.

Schelling, Thomas (1997). Why does economics only help with easy problems? In: Peter A.G. van Bergeijk, A. Lans Bovenberg, Eric E.C. van Damme and Jarig van Sinderen (eds.). Economic Science and Practice: The Role of Academic Economists and Policymakers. Cheltenham, Edward Elgar, 134-148.

Schlecht, Otto and Ulrich van Suntum (eds.) (1995). 30 Jahre Sachverständigenrat zur Begutachtung der gesamtwirtschaftlichen Entwicklung. Krefeld, Sinus.

Schneider, Friedrich, Werner W. Pommerehne and Bruno S. Frey (1983). Relata referimus: Eine Befragung deutscher Ökonomen. Zeitschrift für die gesamte Staatswissenschaft 139 (März), 19-66.

Schneider, Hans-Karl (ed.) (1968). Grundsatzprobleme wirtschaftspolitischer Beratung. Schriften des Vereins für Socialpolitik. Berlin.

Schultze, Charles L. (1996). The CEA: An Inside Voice for Mainstream Economics. Journal of Economic Perspectives 10 (3), 23-39.

Shleifer, Andrei (1998). State versus private ownership. Journal of Economic Perspectives 12 (4), 133-150.

Siegenthaler, Hansjörg (1993). Regelvertrauen, Prosperität und Krisen: die Ungleichmässigkeit wirtschaftlicher und sozialer Entwicklung als Ergebnis individuellen Handels und sozialen Lernens. Tübingen, Mohr.

Siegfried, John J. (1998). Trends in Undergraduate Economics Degrees: A 1996-97 Update. Journal of Economic Education 29, 285-288.

Siegfried, John J. and Wendy A. Stock (1999). The Labor Market für New Ph.D. Economists. Journal of Economic Perspectives 13 (3), 115-134.

Stein, Herbert (1997). A Successful Accident: Recollections and Speculations about the CEA. Journal of Economic Perspectives 10 (3), 3-21.

Stigler, G. J. (1982). The economist as preacher and other essays. Chicago, The University of Chicago Press.

Stigler, George J. (1984). Economics - The Imperial Science? Scandinavian Journal of Economics 86, 301-313.

Stiglitz, Joseph (1997). Looking Out for the National Interest: The Principles of the Council of Economic Advisers. American Economic Review 87 (2), 109-113. 
Stiglitz, Joseph (1998). Distinguished Lecture on Economics in Government: The Private Uses of Public Interests: Incentives and Institutions. Journal of Economic Perspectives 12 (2), 3-22.

Thornton, Robert and John Ward (1999). The Economist in Tort Litigation. Journal of Economic Perspectives 13 (2), 101-112.

Towse, Ruth and Mark Blaug (1988). The Current State of the British Economics Profession. London, RES.

Tullock, Gordon (1984). How to do well while doing good! In: David C. Colander (ed.). Neoclassical Political Economy: The Analysis of Rent-Seeking and DUP Activities. Cambridge, Mass., Ballinger, 229-240.

Von Beckerath, Erwin and Herbert Giersch (eds.) (1963). Probleme der normativen Ökonomik und der wirtschaftspolitischen Beratung. Schriften des Vereins für Socialpolitik. Berlin.

Weber, Luc (1982). Les 'Trois Sages': une necessite ou un anachronisme? Schweizerische Zeitschrift für Volkswirtschaft und Statistik 118 (1), 41-57.

Williamson, J. (1994). In search of a manual for technopols. In: J. Williamson (ed.). The political economy of policy reform. Washington, DC, Institute for International Economics, 11-28.

Williamson, J. (1997). Comments. In: A.W. Coats (ed.). The post-1945 internationalization of economics. Durham, NC, Duke University Press.

Wirtschaftswoche (1997). Der Einfluss der Ökonomen auf die deutsche Wirtschaft- und Finanzpolitik wird immer geringer - mit fatalen Folgen. Nr. 38, 36-43.

Wittman, Donald (1989). Why democracies produce efficient results. Journal of Political Economy 97 (December), 1395-1424.

Zimmermann, Heinz (1999). Financial innovation, the transfer of knowledge, and implications for postgraduate education. In: Ernst Mohr (ed.). The transfer of economic knowledge. Cheltenham, Edward Elgar, 125-150. 


\section{Working Papers of the Institute for Empirical Research in Economics}

No.

1. Rudolf Winter-Ebmer and Josef Zweimüller: Firm Size Wage Differentials in Switzerland: Evidence from Job Changers, February 1999

2. Bruno S. Frey and Marcel Kucher: History as Reflected in Capital Markets: The Case of World War II, February 1999

3. Josef Falkinger, Ernst Fehr, Simon Gächter and Rudolf Winter-Ebmer: A Simple Mechanism for the Efficient Provision of Public Goods - Experimental Evidence, February 1999

4. Ernst Fehr and Klaus M. Schmidt: A Theory of Fairness, Competition and Cooperation, April 1999

5. Markus Knell: Social Comparisons, Inequality, and Growth, April 1999

6. Armin Falk and Urs Fischbacher: A Theory of Reciprocity, April 1999

7. Bruno S. Frey and Lorenz Goette: Does Pay Motivate Volunteers?, May 1999

8. Rudolf Winter-Ebmer and Josef Zweimüller: Intra-firm Wage Dispersion and Firm Performance, May 1999

9. Josef Zweimüller: Schumpeterian Entrepreneurs Meet Engel's Law: The Impact of Inequality on InnovationDriven Growth, May 1999

10. Ernst Fehr and Simon Gächter: Cooperation and Punishment in Public Goods Experiments, June 1999

11. Rudolf Winter-Ebmer and Josef Zweimüller: Do Immigrants Displace Young Native Workers: The Austrian Experience, June 1999

12. Ernst Fehr and Jean-Robert Tyran: Does Money Illusion Matter?, June 1999

13. Stefan Felder and Reto Schleiniger: Environmental Tax Reform: Efficiency and Political Feasibility, July 1999

14. Bruno S. Frey: Art Fakes - What Fakes?, An Economic View, July 1999

15. Bruno S. Frey and Alois Stutzer: Happiness, Economy and Institutions, July 1999

16. Urs Fischbacher, Simon Gächter and Ernst Fehr: Anomalous Behavior in Public Goods Experiments: How Much and Why?: Comment, August 1999

17. Armin Falk, Ernst Fehr and Urs Fischbacher: On the Nature of Fair Behavior, August 1999

18. Vital Anderhub, Simon Gächter and Manfred Königstein: Efficient Contracting and Fair Play in a Simple Principal-Agent Experiment, August 1999

19. Simon Gächter and Armin Falk: Reputation or Reciprocity?, September 1999

20. Ernst Fehr and Klaus M. Schmidt: Fairness, Incentives, and Contractual Choices, September 1999

21. Urs Fischbacher: $z$-Tree - Experimenter's Manual, September 1999

22. Bruno S. Frey and Alois Stutzer: Maximising Happiness?, October 1999

23. Alois Stutzer: Demokratieindizes für die Kantone der Schweiz, October 1999

24. Bruno S. Frey: Was bewirkt die Volkswirtschaftslehre?, October 1999

25. Bruno S. Frey, Marcel Kucher and Alois Stutzer: Outcome, Process \& Power in Direct Democracy, November 1999

26. Bruno S. Frey and Reto Jegen: Motivation Crowding Theory: A Survey of Empirical Evidence, November 1999

27. Margit Osterloh and Bruno S. Frey: Motivation, Knowledge Transfer, and Organizational Forms, November 1999

28. Bruno S. Frey and Marcel Kucher: Managerial Power and Compensation, December 1999

29. Reto Schleiniger: Ecological Tax Reform with Exemptions for the Export Sector in a two Sector two Factor Model, December 1999

30. Jens-Ulrich Peter and Klaus Reiner Schenk-Hoppé: Business Cycle Phenomena in Overlapping Generations Economies with Stochastic Production, December 1999

31. Josef Zweimüller: Inequality, Redistribution, and Economic Growth, January 2000

32. Marc Oliver Bettzüge and Thorsten Hens: Financial Innovation, Communication and the Theory of the Firm, January 2000

33. Klaus Reiner Schenk-Hoppé: Is there a Golden Rule for the Stochastic Solow Growth Model? January 2000

34. Ernst Fehr and Simon Gächter: Do Incentive Contracts Crowd out Voluntary Cooperation? February 2000

35. Marc Oliver Bettzüge and Thorsten Hens: An Evolutionary Approach to Financial Innovation, February 2000

36. Bruno S. Frey: Does Economics Have an Effect? Towards an Economics of Economics, February 2000

The Working Papers of the Institute for Empirical Research in Economics can be downloaded in PDF-format from http://www.unizh.ch/iew/wp/ 